\title{
Winter Precipitation and Snowpack-melt with Temperature and Elevation at Solang Valley, India
}

Anand Verdhen ${ }^{1^{*}}$, Chahar BR $^{1}$ and Sharma $O P^{2}$

${ }^{1}$ Department of Civil Engineering, Indian Institute of Technology, New Delhi, India

${ }^{2}$ Centre for Atmospheric Sciences, Indian Institute of Technology Delhi, New Delhi, India

"Corresponding author: Anand Verdhen, Department of Civil Engineering, Indian Institute of Technology, Hauz Khas, New Delhi-110 016, India, Tel: +919911960776; Email: averdhen4@gmail.com

Rec date: Jan 26, 2016; Acc date: May 11, 2016; Pub date: May 18, 2016

Copyright: $\odot 2016$ Verdhen A, et al. This is an open-access article distributed under the terms of the Creative Commons Attribution License, which permits unrestricted use, distribution, and reproduction in any medium, provided the original author and source are credited.

\begin{abstract}
Knowledge about variability of temperature, precipitation, snowpack and snowmelt with temperature and elevation are essential to prepare input data for hydrological models. The study presents characteristics and variability of these input variables during springtime at three elevations (Bhang, Solang and Dhundi stations in the Solang Valley of the western Himalaya) with respect to mean temperature (Tm) at Bhang using weekly data within a period of 27 years with initial (1982 and 1983) and later (2008 and 2009) consecutive years including decadal years 1993 and 2003. Methodology comprises of process integration using regression, simulation, cluster analysis, transformation, projection and inter-annual comparison. Study shows that temperature lapse rate (TLR) in stretches between snow-free to snow cover area $\left(1.2^{\circ} \mathrm{C} / 100 \mathrm{~m}\right)$ is more than the TLR in stretch of continued snow cover. Temperature, snowfall, rainfall and snow depth per $100 \mathrm{~m}$ of rise in elevation have been estimated as $-1.09^{\circ} \mathrm{C}, 31.2$ $\mathrm{cm},-7.72 \mathrm{~mm}$ and $27.95 \mathrm{~cm}$, respectively. The snowfall and rainfall mixed precipitation occurs within 0.65 and $11.5^{\circ} \mathrm{C}$ of weekly $\mathrm{Tm}$ for which distribution pattern has been developed. Temperature degree-day melt factors, determined in water equivalent term, vary between 2 and $11.5 \mathrm{~mm}^{\circ} \mathrm{C}^{-1} \mathrm{~d}^{-1}$ and it may rise up to $13 \mathrm{~mm}^{\circ} \mathrm{C}^{-1} \mathrm{~d}^{-1}$ for non-zero snow condition. The snow depth excess at Solang $(2450 \mathrm{~m} \mathrm{amsl})$ in relation to Bhang (2190 $\mathrm{m})$ has reduced by $50 \%$ over three decades while the snow depth excess at Dhundi $(2950 \mathrm{~m})$ from the snow depth at Bhang has increased by $15 \%$. Furthermore, disappearance of the snow cover has been experienced earlier by 5 weeks in the region.
\end{abstract}

Keywords: Temperature lapse rate; Rainfall; Snowfall; Normalised snowpack; Linear and cluster analysis; Snowmelt rate variability

\section{Introduction}

Investigation of processes related to temperature, precipitation, snowpack and snowmelt with temperature are important for snowmelt hydrological modelling [1-6]. The study on end-of-winter (spring) snow cover and topographic influence are noteworthy [7]. Uncertainty arises when input variables and parameters are desired for distributed watershed models, while regular observation at higher altitude is difficult [8-10]. Variability in temperature, precipitation, snow cover and melt became more significant due to urbanisation and land use changes during last three decades [11-15]. Pepin [12] documented cooling above $3750 \mathrm{~m}$, but warming between 2500 and $3100 \mathrm{~m}$ since 1952 in the Rocky Mountains of Colorado Front Range, whereas Shekhar et al. [14] found a decrease of $280 \mathrm{~cm}$ in snowfall along with rise in maximum and minimum temperatures by $0.8^{\circ} \mathrm{C}$ and $0.6^{\circ} \mathrm{C}$, respectively since 1988 in the Pir-Panjal Range. Snowmelt reduces to zero during snowfall whereas shallow snow begins to melt earlier [16]. Under such condition of unavailability and uncertainty in data due to lack of observation, change in landscape and climate, it became essential to establish relationship during the period of ablation for projection, interpolation and reliable decision.

The altitude constitutes an important factor in the Himalayan type climatic regions, but lack of observational network necessitates projection and spatial distribution of snow and meteorological input variables. Monthly multiple linear regression relations and modular modelling system (MMS) were used [17] for precipitation and temperature distributions to each homogeneous response units (HRU) whereas Mernild [18] applied Micro-Met for projection and interpolation of precipitation and temperature at higher elevations. Ferguson [19] used frequency distribution analysis for snow water equivalent (SWE). More studies are required to understand the process and its variability with respect to temperature due to change in place, pattern and climatic conditions which has not been attempted and presented adequately.

Temperature is an index to differentiate the snowfall and rainfall phase (snow/rain) and needs site specific relations [20-22]. Researchers $[23,24]$ show drop in temperature due to presence of snow cover (fortnightly depressions of $6^{\circ} \mathrm{C}$ in $\mathrm{T}_{\max }$ and $5^{\circ} \mathrm{C}$ in $\mathrm{T}_{\min }$ ) and snowfall (by $4^{\circ} \mathrm{C}$ from the mean winter air temperature). Therefore, temperature can be also an indicator to distinguish presence and absence of snow cover. Furthermore, temperature based regression analysis was found better than one that is based on precipitation or snow depth [25-27], but the behaviour of precipitation or snow depth with temperature is needed to be explored. Various researchers found different melt factor and needed adjustment in its seasonal and spatial variations [28-33]. Moore and Owens used melt factor in the range of 4 to $8 \mathrm{~mm} /{ }^{\circ} \mathrm{C} /$ day [29]. It has been realized that temperature based precipitation partition, snow cover and snowmelt factors suitable to a region and in general are important to ascertain for application in forecasting, hydrological and water resources development. 
Uncertainties in variability of variables and parameters with time, temperature and elevation under varying climatic conditions invite attention to investigate the data deficient Himalayan watershed for relations and processes involved in snow precipitation and melt components. Therefore, the objective of this study is to determine the temperature, precipitation and snow-depth and snowmelt factor variability with height and weekly spring $\mathrm{Tm}$ at base station. To meet this objective analysis has been performed for two higher stations (Solang and Dhundi) and a base station (Bhang). The study also establishes relation for proportioning rainfall and snowfall amount.

\section{Materials and Methods}

\section{Study region}

The study location (Figure 1) was located in the Solang valley within the Beas sub-basin and the Pir-Panjal Range of the Indian Himalayas. The main stream of Solang Nala (Figure 1) originates at Beas Kund and joins Kothi nala above Bhang to form the River Beas. Seasonal snowline normally descends to 1500 meters above sea level (asl), while less than $2 \%$ of the study area, generally above $5100 \mathrm{~m}$, is occupied by permanent snow/glacier deposits. The area below $3500 \mathrm{~m}$ asl has bushes and coniferous trees, which covers $40 \%$ of the Solang Nala catchment $\left(132 \mathrm{~km}^{2}\right)$ while the area above $3500 \mathrm{~m}$ asl is free from vegetation. The snow and meteorological observation stations in the Himalayas are limited but this small study area in valley within elevation range of 2250 to $5300 \mathrm{~m}$ asl that is exposed mostly to southern aspect has three stations; Bhang ( $32^{\circ} 17^{\prime} \mathrm{N}, 77^{\circ} 12^{\prime} \mathrm{E}, 2192 \mathrm{~m}$ asl), Solang ( $32^{\circ} 19^{\prime} \mathrm{N}, 77^{\circ} 09^{\prime} \mathrm{E}, 2485 \mathrm{~m}$ asl) and Dhundi $\left(32^{\circ} 21.3^{\prime} \mathrm{N}\right.$, $77^{\circ} 7.6^{\prime} \mathrm{E}, 2950 \mathrm{~m}$ amsl). The mean maximum snow depth accumulation was 60,160 and $270 \mathrm{~cm}$, as observed at Bhang, Solang and Dhundi, respectively. Study pertains to snowpack depletion/ melting period which is significant after mid-February and comes to an end by 1st week of May at observation stations.

\section{Methodology}

The meet the objective, the intra seasonal and inter decadal relationships of temperature, precipitation, snow-depth and snowmelt factor with height and temperature at the base station, Bhang have been developed. Study pertains to snowpack depletion/melting period which is significant after mid-February and comes to an end by 1st week of May at observation stations. Weekly and seasonal temperature, rainfall $(\mathrm{mm})$, precipitation (snowfall water equivalent and rainfall in $\mathrm{mm})$, snowfall $(\mathrm{cm})$, snow depth $(\mathrm{cm})$ at all the three stations and their differential data series have been considered for linear regression with respect to maximum temperature $\left(\mathrm{T}_{\max }\right)$, minimum temperature $\left(\mathrm{T}_{\mathrm{min}}\right)$, mean temperature $\left(\mathrm{T}_{\mathrm{m}}\right)$ and diurnal air temperature $\left(\mathrm{T}_{\mathrm{dnl}}=\mathrm{T}_{\max }-\mathrm{T}_{\min }\right)$ at Bhang. Maximum and minimum temperatures $\left(\mathrm{T}_{\max }, \mathrm{T}_{\min }\right)$, rainfall (RF), snowfall (SF) and snow depth (SS) data at Bhang, Solang and Dhundi have been received from Snow and Avalanche Study Establishment (SASE) and used in this study. The weekly data series (covering annual and decadal interval) from 15 February to 2nd May (11 weeks) of 6 years (i.e., 1982, 1983, 1993, 2003, 2008 and 2009) at Bhang, 5 years (not observed in 1993) at Solang and 4 years (observation started since 1993) at Dhundi have been analysed.
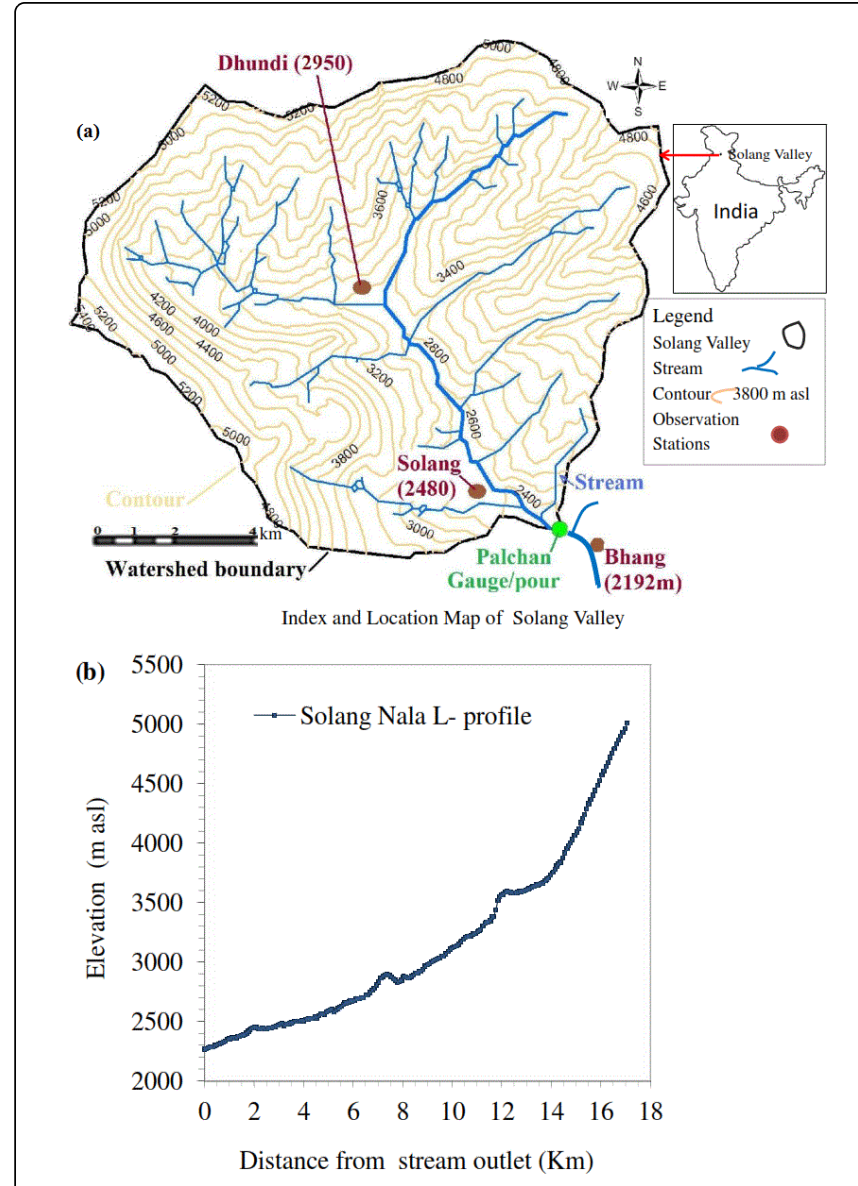

Figure 1: Within Beas sub-basin (a) Index map and observational locations map of Solang Valley in Indian Himalayas, and (b) longitudinal profile of Solang Nala main channel.

The data have been analysed by clubbing them into three groups (P1, its part P2 and P3) for inter-annual and decadal variability, where P1 of each station contains data of all the years, P2 includes data of 1982, 1983 and 1993; while data of 2003, 2008 and 2009 are included in P3. Although few years' data are sufficient to analyze the characteristics of precipitation and snowmelt, 4 to 6 years of springtime weekly data and 26 years of seasonal (November to April) data have indeed helped much to study the processes and pattern.

Temperature: Springtime inter-annual variability of weekly mean temperature $\left(\mathrm{T}_{\mathrm{m}}\right)$ has been assessed with reference to the mean (6th week value) of 1982 at Bhang (B), Solang (S) and Dhundi (D) stations. Based on P1 data series, linear relations of mean temperature at Solang $\left(\mathrm{T}_{\mathrm{mS}}\right)$ and Dhundi $\left(\mathrm{T}_{\mathrm{mD}}\right)$ with respect to Bhang $\left(\mathrm{T}_{\mathrm{mB}}\right)$ have been developed which help in projecting the temperature at higher elevations. Seasonal temperature data from 1982 to 2007 are used to assess the trend and cycle, if any.

Precipitation: Weekly shortfall (-ve) in rain and excess (+ve) of snow at higher elevations (Solang and Dhundi) from the rain and snow at lower elevation (Bhang) have been analysed against temperature series $\left(\mathrm{T}_{\mathrm{mB}}\right)$ at Bhang. Consequently, observed $\left(^{\circ}\right)$ differential rainfall and snowfall have been defined as: 
$-\Delta \mathrm{RF}\left[\right.$ rainfall shortfall at Solang $\left.\left(\mathrm{RF}^{\circ}\right)\right]=$ rainfall at [Solang $\left(\mathrm{RF}^{\circ}\right)$ -
Bhang $\left.\left(\mathrm{RF}^{\circ}\right)\right]$
$-\Delta \mathrm{RF}$ at Dhundi $\left(\mathrm{RF}^{\circ}\right)=$ rainfall at $\left[\mathrm{Dhundi}\left(\mathrm{RF}^{\circ}\right)\right.$-Bhang $\left.\left(\mathrm{RF}^{\circ}\right)\right](1 \mathrm{~b})$
$\Delta \mathrm{SF}$ [snowfall excess at Solang $\left.\left(\mathrm{SF}^{\circ}\right)\right]=$ snowfall [Solang $\left(\mathrm{SF}^{\circ}\right)$-Bhang
$\left.\left(\mathrm{SF}^{\circ}\right)\right]$

\section{$\Delta \mathrm{SF}$ at Dhundi $\left(\mathrm{SF}^{\circ}\right)=$ snowfall at $\left[\mathrm{Dhundi}\left(\mathrm{SF}^{\circ}\right)-\left(\mathrm{SF}^{\circ}\right)\right]$}

When coefficient of determination for regression is less than 0.5 , a cluster based analysis has been envisaged to relate the shift in geometric-centroids of rectangular-clusters, representing impact of climate variability, if any over the period of data group between P2 and P3. The shape of the cluster-geometry may depend on the distribution of data points while we preferred rectangular shape to enclose all points (leaving outliers) to represent mean value and displacement through its centroid.

Snowpack and melt: Similar to the snowfall excess $(\Delta \mathrm{SF})$; weekly snow depth excess $(\triangle \mathrm{SS})$ has been defined:

$\Delta \mathrm{SS}$ [snow depth excess at Solang $\left.\left(\mathrm{SS}^{\circ}\right)\right]=$ snow depth [Solang $\left(\mathrm{SS}^{\circ}\right)-$ Bhang $\left.\left(\mathrm{SS}^{\circ}\right)\right]$

$\Delta S S$ [snow depth excess at Dhundi $\left.\left(\mathrm{SS}^{\circ}\right)\right]=$ snow depth [Dhundi (SS $\left.\left.{ }^{\circ}\right)-\left(\mathrm{SS}^{\circ}\right)\right]$

Regressions have been performed for $\Delta$ SS of Equations (2a and $2 \mathrm{~b}$ ) and SS of each station with $\mathrm{T}_{\mathrm{mB}}$ to establish the relation for data groups P1, P2 and P3. It helps in predicting the variables for different stations and variability over periods based on the temperature of the base station. The centroid of each rectangle enclosing the cluster of P1, $\mathrm{P} 2$ and $\mathrm{P} 3$ data group for $\Delta \mathrm{SF}, \mathrm{SS}$ and $\Delta \mathrm{SS}$ have been identified for the different stations. Local variations of precipitation and snowpack with temperature have been quantified by quantifying the shift in position (change in distance, slope and direction) of the centroid for stations and over period from plot P2 to P3.

The point snowmelt rates $\left(\mathrm{cm}\right.$ or $\mathrm{mm}$ of $\left.\mathrm{SWE}^{\circ} \mathrm{C}^{-1} \mathrm{~d}^{-1}\right)$ have been determined for snow depths at different elevations $\left(\mathrm{SS}_{\mathrm{B}}, \mathrm{SS}_{\mathrm{S}}\right.$ and $\left.\mathrm{SS}_{\mathrm{D}}\right)$, stretches $\left(\mathrm{SS}_{\mathrm{S}-\mathrm{B}}\right.$ and $\left.\mathrm{SS}_{\mathrm{D}-\mathrm{B}}\right)$ and periods $(\mathrm{P} 1, \mathrm{P} 2$, and $\mathrm{P} 3)$ based on the slope of regression with $\mathrm{T}_{\mathrm{mB}}$. Furthermore, the snow depth has been normalised with weekly $T_{m}$ and diurnal range of temperature $\left(T_{d n l}\right)$ to compare the snowpack and its ablation at different stations within 11 weeks of 5 different years (1983, 1993, 2003, 2008 and 2009) :

$$
\mathrm{SS}_{\mathrm{N}(\mathrm{i})}=\left\{\mathrm{SS}_{(\mathrm{i})} \times \mathrm{Tm}_{(\mathrm{i})} / \mathrm{T}_{\mathrm{dnl}(\mathrm{i})}\right\}
$$

where $\mathrm{SS}_{\mathrm{N}}=$ normalised snow depth at stations [cm]; i=weekly count [1 to 11]; SS=snow depth at Bhang, Solang or Dhundi $[\mathrm{cm}] ; \mathrm{T}_{\mathrm{m}}$ and $\mathrm{T}_{\mathrm{dnl}}=$ mean and diurnal temperature of concerned stations $\left[{ }^{\circ} \mathrm{C}\right]$. The temperature in Kelvin to enhances the resolution of $\mathrm{SS}_{\mathrm{N}}$.

Projection to higher elevation: There is lack of information and observation for higher elevation. Therefore, relations to project the variables for the higher elevations in the Solang Valley have been established. Similar to variability over period with P2 (past group) and P3 (recent group) data set, the orographic effect has been determined using P1 data set with reference to temperature at base station. Furthermore, the rate of projection factor (per $100 \mathrm{~m}$ elevation) for $\mathrm{T}_{\mathrm{m}}$, RF, SF and SS variables have been determined with reference to their values at Bhang:

$$
(\mathrm{Y}-\mathrm{X}) / \mathrm{dZ}=[(\mathrm{m}-1) \mathrm{X}+\mathrm{C}] / \mathrm{dZ}
$$

where $\mathrm{Y}=$ value at higher location; $\mathrm{X}=$ value at base location, $\mathrm{dZ}=$ difference in elevation [m asl] between locations divided by $100 ; \mathrm{m}$ and $\mathrm{C}$ are the slope and intercept of the linear regression.

Study on presence of precipitation and snowpack data: Occasionally, there is absence of weekly snowfall, rainfall or snowpack during the study period. Analysing together with repeated zero values may mislead the result. Therefore, the whole data series containing values of RF, SF and SS have been considered for an ideal behaviour of RF, SF and SS with the temperature. In other words it is a particular set of temperatures for rainfall, snowfall and snow depth under which the snowpack development and ablation takes place. Free from zero values of RF and SF trendlines with $\mathrm{T}_{\mathrm{m}}$ have provided critical temperatures (for snowfall and rainfall) and weekly rainfall percent distribution with $\mathrm{T}_{\mathrm{m}}$ (different from $\mathrm{T}_{\mathrm{mB}}$ ). The study has been extended to develop a relation for precipitation partition (rainfall or snowfall percent) and the result have been compared with UBC [34] and Kienzle's [21] approaches and field data. The free from zero weekly SS regression trendline with corresponding weekly $\mathrm{T}_{\mathrm{m}}$ series has provided the maximum degree-day point-melt factor, irrespective of station or change in elevation.

\section{Results and Discussion}

The key results from the analysis of temperature, precipitation (rainfall and snowfall), snow depth and snowmelt variability at base station Bhang and at higher stations (Solang and Dhundi) with reference to temperature and other variables at Bhang are presented and discussed below. Estimation of precipitation partition and changes in variables of data group P2 and P3 over years is also presented.

\section{Temperature}

The period P2 and P3 are almost inter-bi-decadal and found to shrink in variability after seventh week (Figures $2 a$ and $2 b$ ). After the 7th week the rate of decrease in variability of temperature at Bhang is more than Solang. The reason behind this may be absence of snow cover, which occurs after 7 th week at Bhang and during 9 to 10th week at Solang. Interestingly, the variability in temperature is significant over the period if there is snow cover. It means that the temporal variability of temperature due to change in climate is much more significant in snow covered region. Determination of variability in the altitudinal effect on surface temperature is important for its projection and interpolation (Figure 2c) using relations R1a and R1b (Table A1 of Appendix A) on P1 data series of temperature at Solang $\left(\mathrm{T}_{\mathrm{mS}}\right)$ and Dhundi $\left(\mathrm{T}_{\mathrm{mD}}\right)$ with respect to Bhang $\left(\mathrm{T}_{\mathrm{mB}}\right)$, which show good coefficient of determination $\left(\mathrm{R}^{2}=0.91\right)$. The temperature lapse rate (TLR) for Bhang to Solang section comes equal to $1.2^{\circ} \mathrm{C} / 100 \mathrm{~m}$ while TLR for Bhang-Dhundi section comes only $0.73^{\circ} \mathrm{C} / 100 \mathrm{~m}$, which further reduces in Solang-Dhundi section. It shows that TLR in stretch between snow-free to snow cover area is more than the TLR in stretch of continued snow cover. The mean temperature gradient during the snow ablation period for projection in the region with respect to Bhang has been estimated as $-1.09^{\circ} \mathrm{C}$ per $100 \mathrm{~m}$ rise in elevation. There is a trend and cycle of rise in seasonal mean temperature at Bhang and Dhundi (Figure 2d) gaining peak in 1988 and 1999, at an interval of 11 years. 
Citation: Verdhen A, Chahar BR, Sharma OP (2016) Winter Precipitation and Snowpack-melt with Temperature and Elevation at Solang Valley, India. Hydrol Current Res 7: 245. doi:10.4172/2157-7587.1000245

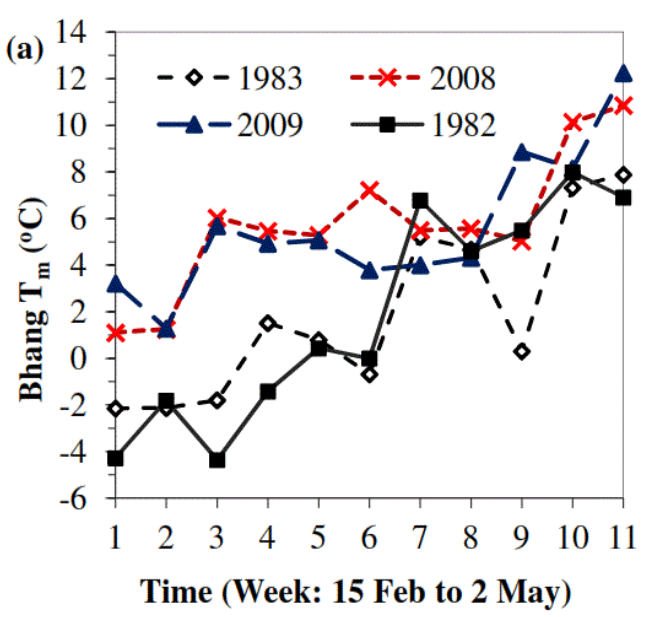

Figure 2a: Weekly mean temperature at Bhang for 1982-1983 under $\mathrm{P} 2$ and 2008-2009 under P2 truncated on its 6th week's $\mathrm{T}_{\mathrm{mB}}$ $\left(6.82^{\circ} \mathrm{C}\right)$ to assess interannual cum bi decadal variability.

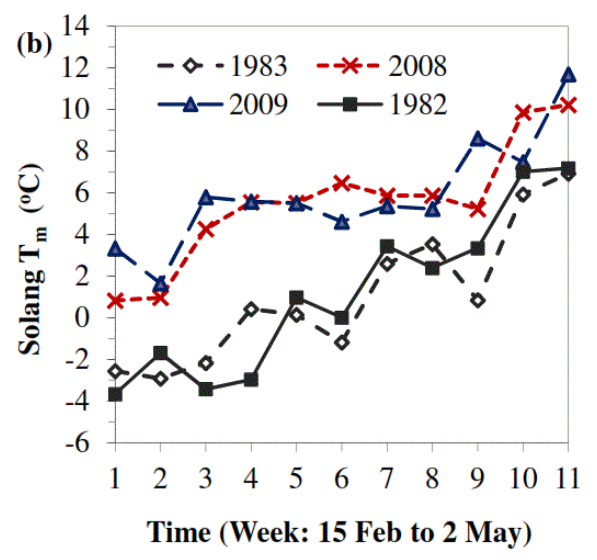

Figure 2b: Weekly mean temperature at Solang for $1982-83$ and 2008-09 truncated on its 6th week's $\mathrm{T}_{\mathrm{mS}}\left(3.04^{\circ} \mathrm{C}\right)$.

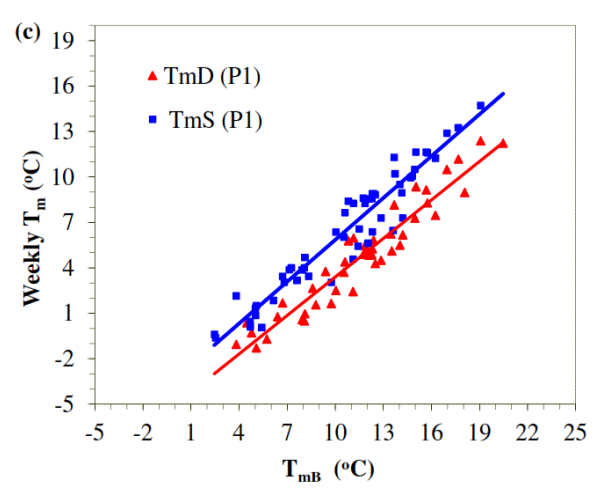

Figure 2c: Weekly mean temperature at Solang and Dhundi versus Bhang $\mathrm{T}_{\mathrm{m}}$ under $\mathrm{P} 1$.

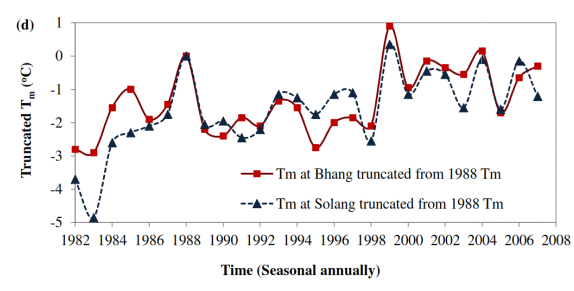

Figure 2d: Seasonal mean temperature at Bhang and Solang from 1982 to 2007 truncated on $1988^{\prime} s \mathrm{~T}_{\mathrm{m}}\left(10.3\right.$ and $\left.7^{\circ} \mathrm{C}\right)$.

\section{Precipitation}

The precipitation during snow cover ablation occurs in the form of snow, rain or mixed. During the study period (from P2 to P3), there is a reduction in spring snowfall (165 to $133 \mathrm{~cm}$ at Bhang and 759 to 408 $\mathrm{cm}$ at Dhundi) and precipitation (676 to $354 \mathrm{~mm}$ of WE at Bhang and 1168 to $691 \mathrm{~mm}$ of WE at Dhundi) while the rainfall at Bhang has decreased from $428 \mathrm{~mm}$ to $305 \mathrm{~mm}$, but rainfall increased from $29 \mathrm{~mm}$ to $79 \mathrm{~mm}$ at Dhundi. This could be due to the impact of climate and land use changes. Evaluation of the variability in precipitation with temperature showed that the weekly precipitations (rainfall and snowfall) at different stations are poorly correlated $\left(R^{2}=0.1\right.$ to 0.5$)$ with $\mathrm{T}_{\mathrm{mB}}$ (Figures $3 \mathrm{a}$ and $3 \mathrm{~b}$ and Figures A1a and A1b). Relations R2a, R2b and $\mathrm{R} 2 \mathrm{c}$ (Table A1) for the rainfall at Bhang $\left(\mathrm{RF}_{\mathrm{B}}\right)$, Solang $\left(\mathrm{RF}_{\mathrm{S}}\right)$ and Dhundi $\left(\mathrm{RF}_{\mathrm{D}}\right)$ with $\mathrm{T}_{\mathrm{mB}}$ are hardly correlated $\left(\mathrm{R}^{2}=0.1\right)$. Rainfall occurs at Bhang, Solang and Dhundi when mean temperature at Bhang crosses 2.5, 5.0 and $10.0^{\circ} \mathrm{C}$, respectively (Figure $3 \mathrm{a}$ ). The rainfall occurrence distribution with $\mathrm{T}_{\mathrm{mB}}$ is left-skewed at Bhang while it is right-skewed at Solang and Dhundi which reveals higher liquid precipitation at Bhang than Dhundi during snow storm. The relations for shortfall in rainfall $(-\Delta \mathrm{RF})$ at Solang and Dhundi with respect to Bhang against $\mathrm{T}_{\mathrm{mB}}$ for $\mathrm{P} 2$ and $\mathrm{P} 3$ in Table A1 (see R3a, R3b, R3c and R3d) compute increase in rainfall at Solang from period P2 to P3 and no rain at Bhang above $11.3^{\circ} \mathrm{C}$ during $\mathrm{P} 2$ and $14.4^{\circ} \mathrm{C}$ during $\mathrm{P} 3$. It indicates that spring time (15 February to 2 May) temperature during P3 is warmer than P2.

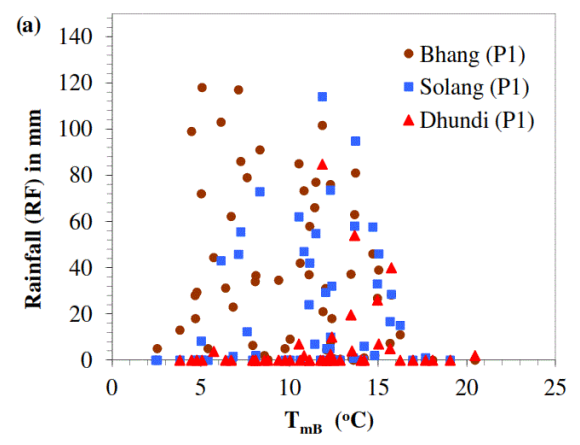

Figure 3a: Weekly precipitation at Bhang, Solang and Dhundi under $\mathrm{P} 1$ against $\mathrm{T}_{\mathrm{mB}}$ for rainfall (in $\mathrm{mm}$ ). 


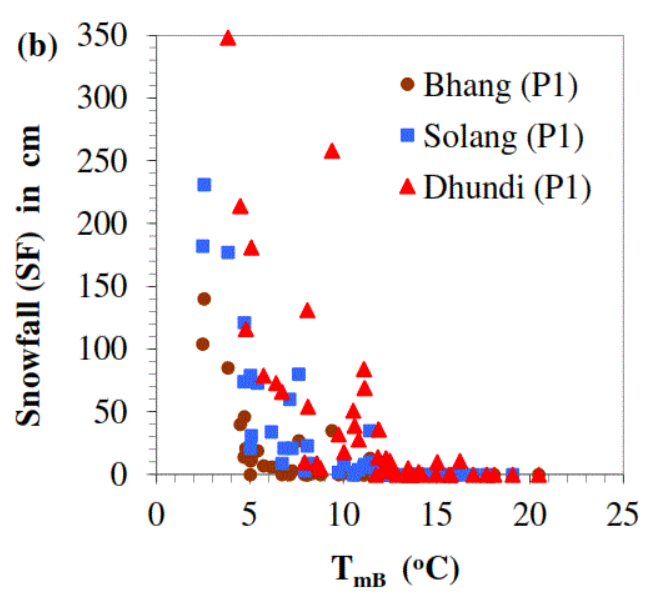

Figure 3b: Weekly precipitation at Bhang, Solang and Dhundi under $\mathrm{P} 1$ against $\mathrm{T}_{\mathrm{mB}}$ for snowfall $(\mathrm{cm})$.

Spring snow storms formed only $50 \%$ of the seasonal snowfall in P2 and $25 \%$ in P3. Linear regression (Figure $3 b$ ) relations for P1 (R4a-c) between $\mathrm{SF}$ and $\mathrm{T}_{\mathrm{mB}}$ with low coefficient of determination $\left(\mathrm{R}^{2}=0.3\right.$ to 0.51 ) hint that a significant part of the variance depends upon other factors i.e., relative humidity, pressure and cloud conditions. The spring snowfall are $43.0 \mathrm{~cm}$ (Bhang), $118.0 \mathrm{~cm}$ (Solang) and $190.0 \mathrm{~cm}$ (Dhundi) at $\mathrm{T}_{\mathrm{mB}}=0.0^{\circ} \mathrm{C}$, while there is no snowfall at Bhang above $9^{\circ} \mathrm{C}$ and at any of the stations when $\mathrm{T}_{\mathrm{mB}}>14.5^{\circ} \mathrm{C}$. It means that the weekly mean temperature of snowfall termination at Dhundi is $(14.5-0.73 \times$ $(2950-2192))=8.97^{\circ} \mathrm{C}$. Similar snowfall termination temperatures can be computed using TLR and elevation for Solang. Further analysis for snowfall and rainfall together in water equivalent (WE) form on an average snow density of $0.1 \mathrm{gm} / \mathrm{cc}$. with $\mathrm{T}_{\mathrm{mB}}$ and $\mathrm{T}_{\mathrm{dnl}}$ using P1 data series shows that the precipitation $(\mathrm{PR})$ in the study region ceases at $\mathrm{T}_{\mathrm{mB}}$ or $\mathrm{T}_{\mathrm{dnl}}=16.8^{\circ} \mathrm{C}$. Whereas, $\mathrm{PR}$ commences when weekly $\mathrm{T}_{\mathrm{dnl}}$ is between 7.5 and $9^{\circ} \mathrm{C}$.

Snowfall excess $(\triangle \mathrm{SF})$ at Solang and Dhundi to Bhang with $\mathrm{T}_{\mathrm{mB}}$ for P1, P2 (Figure A1a) and P3 (Figure A1b) and trend-line (relations R5a$\mathrm{f}$ in Table A1) show that $\Delta \mathrm{SF}$ at Dhundi increases whereas it reduces at Solang over the period corresponding to $\mathrm{T}_{\mathrm{mB}}$ (discussed in Appendix A2).

\section{Snow depth and melt}

Trendline of snow depth (SS) at all the stations for P1 against $\mathrm{T}_{\mathrm{mB}}$ (relations R6a-c) and trajectory of clusters' centroid (Figure 4a) show higher rate of ablation at Bhang-Solang section than Solang-Dhundi section. It presents the status of snowpack, i.e., SS of 39, 215 and 239 $\mathrm{cm}$ at $\mathrm{B}, \mathrm{S}$ and $\mathrm{D}$ stations, respectively at melt-freeze temperature at Bhang, $\mathrm{T}_{\mathrm{mB}}=0.0^{\circ} \mathrm{C}$. While, $\mathrm{SS}_{\mathrm{B}}, \mathrm{SS}_{\mathrm{S}}$ and $\mathrm{SS}_{\mathrm{D}}$ vanishes at $13.8,15.4$ and $19.3^{\circ} \mathrm{C}$ of $\mathrm{T}_{\mathrm{mB}}$, respectively with $\mathrm{R}^{2}=0.4$ to 0.6 . The estimated melt rate at $\mathrm{B}, \mathrm{S}$ and $\mathrm{D}$ comes to $2.85,13.98$ and $12.37 \mathrm{~cm} /{ }^{\circ} \mathrm{C} /$ week, respectively with $\mathrm{T}_{\mathrm{mB}}$ (R6a-c of Table A1). The lower melt rate at Bhang may be due to insufficient snow depth to utilize the available potential degreeday. Nevertheless, the lower melt rate due to thin and partial snow cover is critical and important.

Weekly snow depth excess $\left(\mathrm{SS}_{\mathrm{S}-\mathrm{B}}\right.$ and $\mathrm{SS}_{\mathrm{D}-\mathrm{B}}$ ) series analysed with respect to $\mathrm{T}_{\mathrm{mB}}$ using data group $\mathrm{P} 1, \mathrm{P} 2$, and $\mathrm{P} 3$ with relations (R7a-f) in Table A1 provides snowpack related characteristics with reference to temperature and snow depth at Bhang in average and over period. Centroid of cluster-boxes shows variability in $\Delta$ SS from period P2 to P3 due to change in climate (Figures $4 \mathrm{~b}$ and $4 \mathrm{c}$ ). Relations (R7c and R7d) in Table A1 for period P2 yield $S_{S-B}=181 \mathrm{~cm}$ and $S_{D-B}=203 \mathrm{~cm}$, whereas relations (R7e and $\mathrm{R} 7 \mathrm{f}$ ) for $\mathrm{P} 3$ yield $\mathrm{SS}_{\mathrm{S}-\mathrm{B}}=94 \mathrm{~cm}$ and $\mathrm{SS}_{\mathrm{D}-}$ ${ }_{\mathrm{B}}=238 \mathrm{~cm}$ at $\mathrm{T}_{\mathrm{mB}}=0.0^{\circ} \mathrm{C}$. Result reveals that from period $\mathrm{P} 2$ to $\mathrm{P} 3, \Delta \mathrm{SS}$ at Solang is reduced by $50 \%$ and $\Delta S$ S at Dhundi is increased by $15 \%$ at $\mathrm{T}_{\mathrm{mB}}=0.0^{\circ} \mathrm{C}$. Furthermore, snowpack at $\mathrm{S}$ and $\mathrm{D}$ disappears at $\mathrm{T}_{\mathrm{mB}}$ of 21.3 and $22.7^{\circ} \mathrm{C}$ respectively in period $\mathrm{P} 2$ whereas in $\mathrm{P} 3$ it disappears at 15.4 and $17.7^{\circ} \mathrm{C}$. A fall in $\mathrm{T}_{\mathrm{mB}}$ over period $\mathrm{P} 2$ to $\mathrm{P} 3$ indicates snowpack disappearance at 6 to $5^{\circ} \mathrm{C}$ lower $\mathrm{T}_{\mathrm{mB}}$ during period $\mathrm{P} 3$. Interestingly, the temperature lag between snowfall disappearance and snowpack disappearance has reduced from past (P2) to present (P3) which leads to destructive impact on the health of the snowpack. Consequently, snow cover disappearance has advanced almost by 5 weeks: the snowpack duration at B, S, and D of 7, 11 and $>11$ weeks, respectively in $\mathrm{P} 2$ has reduced to 2, 6 and 9 weeks, respectively in P3. If runoff data is available, snowpack depth/melt vs runoff relation under average condition can be developed [35] for the runoff prediction.

The snowpack ablation and melt rate information is important for snow hydrology. The Daily ablation (DA) of snow depth (in $\mathrm{cm} /{ }^{\circ} \mathrm{C} /$ day) gives snowpack ablation while DA of SWE (in $\mathrm{mm} /{ }^{\circ} \mathrm{C} /$ day) gives melt rate with $\mathrm{T}_{\mathrm{mB}}$ and $\mathrm{T}_{\max }$ at Bhang for all the stations (Table 1). The melt rate (in SWE) is between 2.6 and $10.8 \mathrm{~mm} /{ }^{\circ} \mathrm{C} /$ day during $\mathrm{P} 2$ (past) while it ranges from 1.2 to $11.8 \mathrm{~mm} /{ }^{\circ} \mathrm{C} /$ day during $\mathrm{P} 3$ (present). It is relevant to note that there is decrease in melt rate with increase in numbers of snow-free weeks/days. Seasonal average snowmelt of 2.1 $\mathrm{mm} /{ }^{\circ} \mathrm{C} /$ day computed on observed snowmelt of $706 \mathrm{~mm}$ in 90 days at $3.75^{\circ} \mathrm{C}$ of average temperature at Dhundi [31] falls in the tail end range of weekly melt rate (1.2 to $11.8 \mathrm{~mm} /{ }^{\circ} \mathrm{C} /$ day).

\begin{tabular}{|c|c|c|c|c|c|c|c|c|c|}
\hline \multicolumn{2}{|l|}{ Location } & \multicolumn{5}{|c|}{$\begin{array}{l}\text { DA } \\
\left(\mathrm{cm} /{ }^{\circ} \mathrm{C} / \text { day }\right)\end{array}$} & \multicolumn{3}{|c|}{$\begin{array}{l}\text { Melt rate } \\
\text { (mm of SWE } /{ }^{\circ} \mathrm{C} / \text { day) }\end{array}$} \\
\hline Altitude & Temp. & P1 & P2 & $R^{2}$ & P3 & $\mathrm{R}^{2}$ & P2 & P3 & Inference \\
\hline B (2192) & $\mathrm{T}_{\mathrm{mB}}$ & 0.41 & 0.47 & 0.39 & 0.22 & 0.42 & 2.6 & 1.2 & decreases \\
\hline S (2485) & $T_{m B}$ & 2 & 1.96 & 0.67 & 1.09 & 0.45 & 10.8 & 6 & decreases \\
\hline D (2950) & $T_{m B}$ & 1.77 & 0.97 & 0.35 & 2.14 & 0.52 & 5.3 & 11.8 & increases \\
\hline$\Delta S S_{S-B}$ & $T_{\max }$ & & 0.94 & 0.47 & 0.66 & 0.32 & 5.2 & 3.7 & \\
\hline
\end{tabular}


Citation: Verdhen A, Chahar BR, Sharma OP (2016) Winter Precipitation and Snowpack-melt with Temperature and Elevation at Solang Valley, India. Hydrol Current Res 7: 245. doi:10.4172/2157-7587.1000245

Page 6 of 11

\begin{tabular}{|c|c|c|c|c|c|c|c|c|}
\hline & $\mathrm{T}_{\mathrm{mB}}$ & 1.22 & 0.5 & 0.88 & 0.37 & 6.7 & 4.8 & decreases \\
\hline & $T_{\max }$ & 0.7 & 0.26 & 1.51 & 0.43 & 3.8 & 8.3 & \\
\hline$\Delta \mathrm{SS}_{\mathrm{D}-\mathrm{B}}$ & $\mathrm{T}_{\mathrm{mB}}$ & 0.89 & 0.3 & 1.93 & 0.47 & 4.9 & 10.6 & increases \\
\hline Inference & & \multicolumn{7}{|c|}{$\begin{array}{l}\text { DA with } T_{\max } \text { is less than } T_{m B} \text { and rising with elevation. Regression coefficient, } R^{2} \text { is not good as it has effect of fresh snow, wind } \\
\text { drift, settlement, albedo, cloud cover, aspect exposure, forest cover, days with no snow pack, and anthropological activities. } \\
\text { Regional value of } 11.8 \mathrm{~mm} /{ }^{\circ} \mathrm{C} / \text { day on } T_{m B} \text { and decrease in other values this indicate absence of snow cover days/week } \\
\text { correspondingly. }\end{array}$} \\
\hline
\end{tabular}

Table 1: Interspatial periodical snowpack melt rate with temperatures at Bhang: Daily ablation (DA) of snow depth (in $\left.\mathrm{cm} /{ }^{\circ} \mathrm{C} / \mathrm{day}\right)$ and $\mathrm{DA}$ of SWE (in $\mathrm{mm} /{ }^{\circ} \mathrm{C} /$ day) with $\mathrm{T}_{\mathrm{mB}}$ and $\mathrm{T}_{\max }$ at Bhang for all the stations and $\Delta \mathrm{SS}$ at Solang and Dhundi using P2 and P3 data. Notes: Snowpack density $=0.55 \mathrm{gm} / \mathrm{cc}[\mathrm{mm}] ; \mathrm{SS}_{\mathrm{S}-\mathrm{B}}=$ Snow depth excess at Solang and $\mathrm{SS}_{\mathrm{D}-\mathrm{B}}=$ Snow depth excess at Dhundi from Bhang; $\mathrm{T}_{\mathrm{mB}}$ and $\mathrm{T}_{\mathrm{max}}=$ weekly mean and maximum temperatures at Bhang $\left[{ }^{\circ} \mathrm{C}\right]$; P2=data series of 1982, 1983 and 1993; P3=data series of 2003, 2008 and 2009 (missing data year: 1993 at Solang and 1982 and 1983 at Dhundi).

Time series plots of normalised standing snow $\left(\mathrm{SS}_{\mathrm{N}}\right)$ of Bhang, Solang and Dhundi with $\mathrm{T}_{\mathrm{mB}}$ (Figure $4 \mathrm{~d}$ ) reveal impact of rising air temperature in terms of reduced snow depth over two decades. It is relevant to note that weekly snowmelt or snowpack ablation rate at different elevations/stations remain uniform with usual lag at higher elevation, but weekly snow profile at Dhundi, even located at $465 \mathrm{~m}$ higher, has depleted as low as of Solang in previous years. Consequently, relevance of time series analysis has gone down.

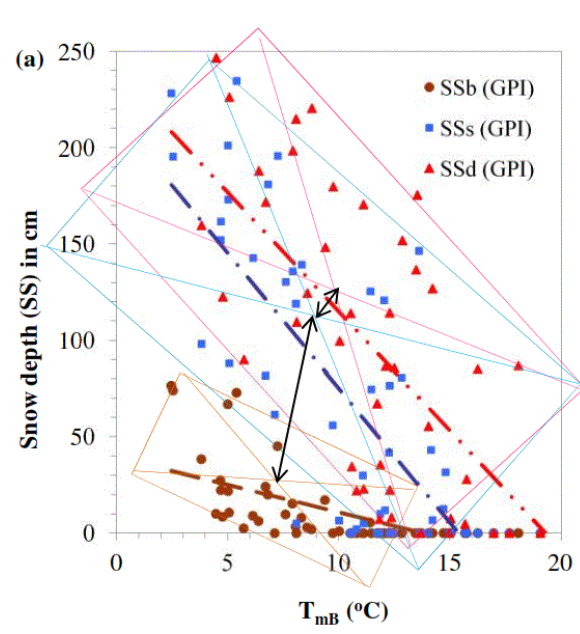

Figure 4a: Weekly snow depth (cm) vs $\mathrm{T}_{\mathrm{mB}}$ for (a) snow depth (SS) of Bhang, Solang and Dhundi including rectangular-cluster's centroids under P1.

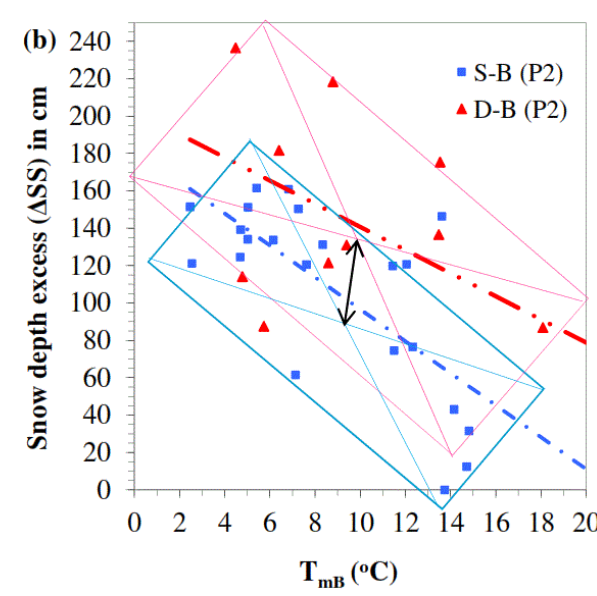

Figure 4b: Weekly snow depth $(\mathrm{cm})$ vs. $\mathrm{T}_{\mathrm{mB}}$ for $\mathrm{SS}_{\mathrm{S}-\mathrm{B}}$ and $\mathrm{SS}_{\mathrm{D}-\mathrm{B}}$ including rectangular-cluster's centroids under $\mathrm{P} 2$.

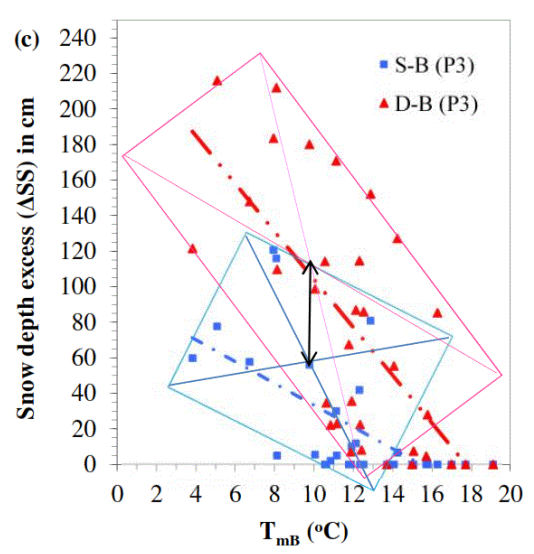

Figure 4c: Weekly snow depth $(\mathrm{cm})$ vs $\mathrm{T}_{\mathrm{mB}}$ for $\mathrm{SS}_{\mathrm{S}-\mathrm{B}}$ and $\mathrm{SS}_{\mathrm{D}-\mathrm{B}}$ including rectangular-cluster's centroids under $\mathrm{P} 3$. 


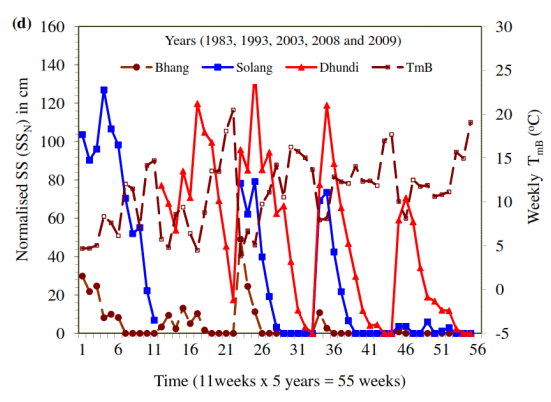

Figure 4d: Weekly snow depth (cm) vs $\mathrm{T}_{\mathrm{mB}}$ for weekly time series of normalised snow depth $\left(\mathrm{SS}_{\mathrm{N}}\right)$ at Bhang, Solang (1993na) and Dhundi (1983na) and $\mathrm{T}_{\mathrm{mB}}$ series from 15 February to 2 May (11 weeks) for the years 1983, 1993, 2003, 2008 and 2009.

\section{Projection to higher elevations}

Spatially distributed hydrological model requires temperature, precipitation and snow depth at different elevations which may be obtained from the base station in lack of observational network. Projection of mean air temperature at Solang and Dhundi with respect to the station at Bhang has been discussed in 'temperature' section (Figure 2c; R1a-d of Table A1). Relations R8a, R8b and R8c (Table A1) give the rate of projection per $100 \mathrm{~m}$ rise in elevation for snowfall, rainfall and snow depth in Bhang-Solang section while relations R8d, R8e and R8f (Table A1) give the rate of projection in Bhang-Dhundi section. These relations result in gradient during the snow ablation period in the region as $31.2 \mathrm{~cm},-7.72 \mathrm{~mm}$ and $27.95 \mathrm{~cm}$ for SF, RF and SS, respectively wherein gradient is with respect to per $100 \mathrm{~m}$ rise in elevation.

\section{Study on prevailing snowpack and precipitation data}

Furthermore, snowpack ablation and spring precipitation data series free from zero present relation with temperature (Figure 5a) irrespective of time and elevation. It is interesting to depict the lowest $\mathrm{T}_{\mathrm{m}}\left(\mathrm{T}_{\mathrm{sf}}\right)=0.65^{\circ} \mathrm{C}$ for no-rain or only snow and the highest $\mathrm{T}_{\mathrm{m}}$ $\left(T_{\mathrm{rf}}\right)=11.5^{\circ} \mathrm{C}$ for only rain or no fresh snow. These envisaged turning point temperatures $\left(\mathrm{T}_{\mathrm{sf}}\right.$ and $\left.\mathrm{T}_{\mathrm{rf}}\right)$ are also used for snowline and snow cover development [36]. Therefore, temperature range $\left(\mathrm{TR}=\mathrm{T}_{\mathrm{rf}}-\mathrm{T}_{\mathrm{sf}}\right)$ is $10.85^{\circ} \mathrm{C}$ with a probability of both rain and snow. Consequently, the mean critical temperature $\left(\mathrm{T}_{\mathrm{crs}}\right)$ of $4.4^{\circ} \mathrm{C}$, where the rain and snow has equal chance of occurrence, has been determined using Kienzle's relation (Figure 5b).

It is difficult to decide about the snowfall and rainfall proportions from the estimated/projected value of precipitation (WE) at the higher elevation. Hence, a simple relation resulting in the precipitation factor for the rain portion (Prain) has been developed and simulated (Figure 5b) using $\mathrm{T}_{\mathrm{sf}}, \mathrm{T}_{\mathrm{crs}}, \mathrm{T}_{\mathrm{rf}}$ and Tm yielding,

$$
\text { Prain }=\left(-\mathrm{T}_{\mathrm{sf}} \times \mathrm{T}_{\mathrm{m}} 3+\mathrm{T}_{\text {crs }} \times \mathrm{T}_{\mathrm{m}} 2-\mathrm{T}_{\mathrm{rf}} \times \mathrm{T}_{\mathrm{m}}\right) / 100
$$

where $T_{\text {sf }}, T_{\text {crs }}$ and $T_{\text {rf }}$ are constants on weekly time scale. All the four temperature inputs in Equation (5a) have physical significance. Moreover, auto-multiple regression (Figure $5 b$ ) of observed data on Prain and $\mathrm{T}_{\mathrm{m}}$ has yielded the following relation,

$$
\text { Prain }=-0.006 \mathrm{~T}_{\mathrm{m}}^{2}+0.166 \mathrm{~T}_{\mathrm{m}}-0.032
$$

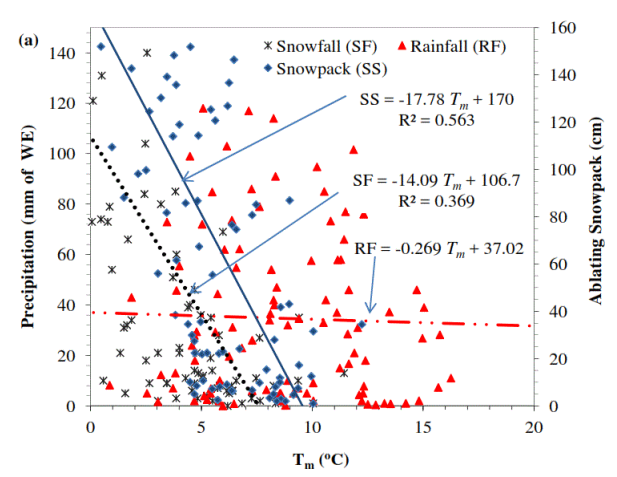

Figure 5a: Relation of weekly snow depth, snowfall (WE) and rainfall with mean air temperature $\left(\mathrm{T}_{\mathrm{m}}\right)$ for all the data series free from zero values of SS, SF, and RF at the stations (i.e., irrespective of time and elevation) SS, SF, and RF data series of more than zero values vs. $\mathrm{T}_{\mathrm{m}}$ in Solang valley.

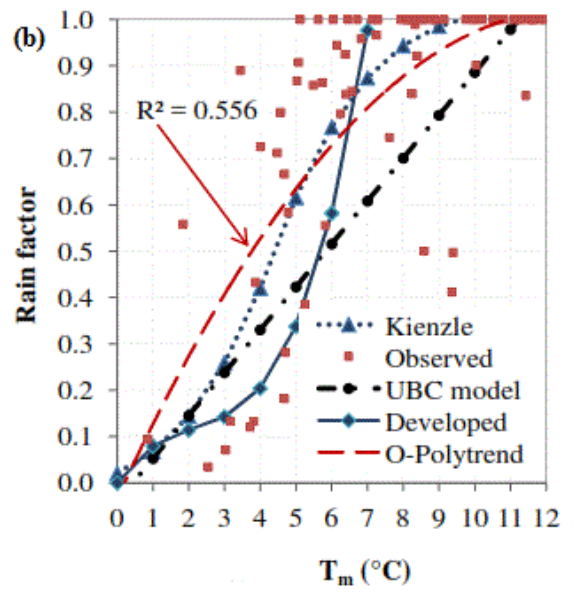

Figure 5b: Relation of weekly snow depth, snowfall (WE) and rainfall with mean air temperature $\left(\mathrm{T}_{\mathrm{m}}\right)$ for all the data series free from zero values of SS, SF, and RF at the stations (i.e., irrespective of time and elevation) rainfall portion of precipitation model as per observed data, Kienzle, UBC, developed and poly-trend within 0.0 to $12^{\circ} \mathrm{C}$ range of $\mathrm{T}_{\mathrm{m}}$.

Relations of UBC [34] and Kienzle [21] for the phase of precipitation are given in Appendix A3 by Equation (A.2) and Equations (A.3a-b), respectively. The comparison between computed phases of precipitation on simulation developed Equation (5a), linear approach of UBC, curvilinear approach of Kienzle, auto-multiple regression Equation (5b) and observed precipitation (Figure 5b) reveals better visual result for Equation (5a) than for later three approaches. Regression coefficient $\left(\mathrm{R}^{2}\right)$ on observed vs. computed phase of precipitation (Figure $5 \mathrm{c}$ ) resulted in $0.42,0.58,0.52$ and 0.56 for the UBC, Kienzle, simulated and regressed relations, respectively. This shows that Equation (5a) developed is not only in agreement with Kienzle's approach (Appendix A3) but it is also simple to use globally. 
Citation: Verdhen A, Chahar BR, Sharma OP (2016) Winter Precipitation and Snowpack-melt with Temperature and Elevation at Solang Valley, India. Hydrol Current Res 7: 245. doi:10.4172/2157-7587.1000245

Page 8 of 11

Subsequently, the ideal snowpack melt gradient (dSS/dT) or melt factor $\left(\mathrm{M}_{\mathrm{f}}\right)$ has been determined from (SS vs. $\mathrm{T}_{\mathrm{m}}$ ) trend-line (Figure $5 \mathrm{a}$ and R9) or from the following equation:

$$
\mathrm{SS}=-17.78 \mathrm{~T}_{\mathrm{m}}+170:\left\{\mathrm{M}_{\mathrm{f}}=\mathrm{dSS} / \mathrm{dT}=17.78\right\}
$$

where $\mathrm{M}_{\mathrm{f}}=17.78=$ standing snow depletion per degree temperature $\left[\mathrm{cm} /{ }^{\circ} \mathrm{C} /\right.$ week or $0.714 \mathrm{~mm} /{ }^{\circ} \mathrm{C} / \mathrm{d}$ of SWE]. This point-melt includes the evaporation, sublimation; condensation and ground melt of the hydrological processes. The range of daily snowmelt on weekly average basis using different melt algorithms [37] shows conformity with this result.

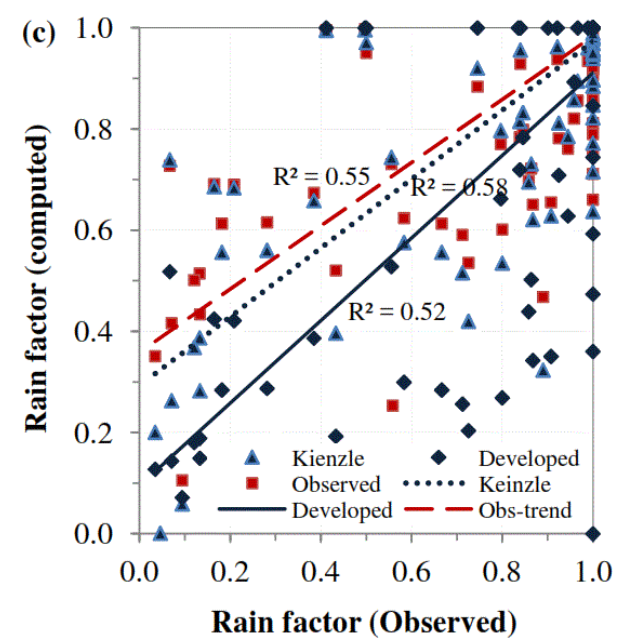

Figure 5c: Relation of weekly snow depth, snowfall (WE) and rainfall with mean air temperature $\left(\mathrm{T}_{\mathrm{m}}\right)$ for all the data series free from zero values of SS, SF, and RF at the stations (i.e., irrespective of time and elevation) efficiency verification of precipitation (rain/ snow) partition models of Kienzle and developed under this study with the observed data.

\section{Conclusions}

Temperature lapse rate, rainfall, snowfall, snow depth and melt rate data are important for snowmelt modelling. Linear regression with temperature has been found quite good to be adopted for spatial projection, interpolation and variability detection. SS, SF, RF, and $\mathrm{T}_{\mathrm{m}}$ projections from the base station (Bhang) in $100 \mathrm{~m}$ of rise in elevation are $27.95 \mathrm{~cm}, 31.2 \mathrm{~cm},-7.72 \mathrm{~mm}$ and $-1.09^{\circ} \mathrm{C}$, respectively. The $\mathrm{R}^{2}$ for SF, RF, SS and Tm analysis falls in the range of 0.4 to $0.6,0.60$ to 0.9 , $<0.5$ and $>0.9$, respectively. The lower value of $\mathrm{R}^{2}$, i.e., $\mathrm{SS}$ and $\mathrm{RF}$ necessitates for envisaged cluster based analysis to track the variability on mean of the scatter. The inter-decadal variability of spring temperature in the region is telescopic from the first week of spring to eleventh week. This means that the air temperature over ablating snow is more sensitive to climate variability than the temperature over snowfree area.
The snowpack at Solang and Dhundi disappears earlier and at about $5^{\circ} \mathrm{C}$ lower weekly mean temperature at Bhang at present (P3) in relation to past (P2 data set). Snowfall at Dhundi/Solang/Bhang ceases by $9^{\circ} \mathrm{C}$ and rainfall occasionally occurs whenever $\mathrm{T}_{\mathrm{mB}}$ exceeds $14.9^{\circ} \mathrm{C}$. The precipitation and snowfall amount at each station attain maximum for $\mathrm{T}_{\mathrm{m}}=4^{\circ} \mathrm{C}$ and $\mathrm{T}_{\mathrm{dnl}}=7.5^{\circ} \mathrm{C}$; however spring precipitation is minimal when $\mathrm{T}_{\mathrm{mB}}$ or $\mathrm{T}_{\mathrm{dnl}}$ reaches $16.8^{\circ} \mathrm{C}$. It has also been noted that there is no rainfall below $0.65^{\circ} \mathrm{C}$ and no snowfall above $11.5^{\circ} \mathrm{C}$ of weekly $\mathrm{T}_{\mathrm{m}}$ so relation of mixed phase of precipitation has been developed, which may be valid for all the snowy watersheds.

Study reveals that the melting away of complete snow has been advanced by 5 weeks at lower stations (Bhang/Solang) and the snow accumulation has been reduced by $50 \%$ at Solang over the study duration (1982-2009). Degree-day snowpack ablation (melt) varies between 1.2 and $11.8 \mathrm{~mm}$ of $\mathrm{SWE}^{\circ} \mathrm{C}^{-1} \mathrm{~d}^{-1}$. Degree-day melt decreases in the Bhang-Solang section, due to discontinued and low snow depth. However, the maximum snowmelt rate has gone up by $12.7 \mathrm{~mm}$ of $\mathrm{SWE}^{\circ} \mathrm{C}^{-1} \mathrm{~d}^{-1}$ irrespective of elevation.

The relationships of snowfall, rainfall, snowpack and melt-rate with temperature developed for the Solang valley provide sufficient understanding for the snowmelt hydrological component processes of the Beas sub-basin and are applicable in the data deficient mountainous region.

\section{Acknowledgments}

Authors acknowledge Mr. Ashwagosha Ganju, Director and Mr. N. K. Thakur, Deputy Director of Snow and Avalanche Study Establishment, India for data.

\section{Appendix A. Inter-station Temperature and Precipitation-phases}

\section{A1. Temperature lapse rate variability}

TLR between Bhang and Solang section comes equal to,

$$
\mathrm{TLR}=\left[100 \times(3.66+3.37) /(2 \times(2485-2192)]=1.2^{\circ} \mathrm{C} / 100 \mathrm{~m}\right.
$$

While for Solang and Dhundi section,

$$
\mathrm{TLR}=\left[100 \times(6.0+5.09) /(2 \times(2950-2192)]=0.73^{\circ} \mathrm{C} / 100 \mathrm{~m}\right.
$$

Where Dhundi, Solang and Bhang stations are at 2950, 2485 and $2192 \mathrm{~m}$ asl, respectively.

\section{A2. Variability of precipitation}

The difference in precipitations between two stations with temperature series for $\mathrm{P} 2$ and $\mathrm{P} 3$ provide spatio-temporal variability in precipitation. The rainfall shortfall $(\triangle \mathrm{RF})$ at Solang and Dhundi against $\mathrm{T}_{\mathrm{mB}}$ for $\mathrm{P} 2$ and $\mathrm{P} 3$ are given by relations $\mathrm{R} 3 \mathrm{a}-\mathrm{d}$ of Table A1. The shortfall in rainfall at Solang below $11^{\circ} \mathrm{C}$ at Bhang is more in P2

\begin{tabular}{|l|l|l|l|l|l|l|l|}
\hline Regression Relation & $\mathbf{R}^{2}$ & Rel. No. & Regression Relation (Rel.) & $\mathbf{R}^{2}$ & Rel. No. & & Group: Figure Reference \\
\hline $\mathrm{T}_{\mathrm{mD}}=0.847 \mathrm{~T}_{\mathrm{mB}}-5.09$ & 0.92 & $\mathrm{R} 1 \mathrm{a}$ & $\mathrm{T}_{\mathrm{ms}}=0.92 \mathrm{~T}_{\mathrm{mB}}-3.367$ & 0.92 & $\mathrm{R} 1 \mathrm{~b}$ & $\mathrm{Tm}$ & $\mathrm{P} 1 ;$ Figure $2 \mathrm{c}$ \\
\hline $\mathrm{dT} /\left.\mathrm{dZ}\right|_{\mathrm{BS}}=-0.03 \mathrm{~T}_{\mathrm{mB}}-1.15$ & 0.9 & $\mathrm{R} 1 \mathrm{c}$ & $\mathrm{dT} /\left.\mathrm{dZ}\right|_{\mathrm{BD}}=-0.02 \mathrm{~T}_{\mathrm{mB}}-0.67$ & 0.9 & $\mathrm{R} 1 \mathrm{~d}$ & $\mathrm{TLR}$ & $\mathrm{P} 1 ;$ Figure 2c \\
\hline
\end{tabular}


Citation: Verdhen A, Chahar BR, Sharma OP (2016) Winter Precipitation and Snowpack-melt with Temperature and Elevation at Solang Valley, India. Hydrol Current Res 7: 245. doi:10.4172/2157-7587.1000245

Page 9 of 11

\begin{tabular}{|c|c|c|c|c|c|c|c|}
\hline $\mathrm{RF}_{\mathrm{B}}=-2.53 \mathrm{~T}_{\mathrm{mB}}+60.2$ & $\mathrm{nc}$ & $\mathrm{R} 2 \mathrm{a}$ & $\mathrm{RF}_{\mathrm{s}}=1.13 \mathrm{~T}_{\mathrm{mB}}+7.98$ & $\mathrm{nc}$ & $\mathrm{R} 2 \mathrm{~b}$ & RF & P1; Figure 3a \\
\hline $\mathrm{RF}_{\mathrm{D}}=0.67 \mathrm{~T}_{\mathrm{mB}}-1.67$ & $\mathrm{nc}$ & $\mathrm{R} 2 \mathrm{c}$ & & & & RF & P1; Figure 3a \\
\hline $\mathrm{RF}_{\mathrm{B}-\mathrm{S}}=-2.598 \mathrm{~T}_{\mathrm{mB}}+46.01$ & $\mathrm{nc}$ & R3a & $\mathrm{RF}_{\mathrm{B}-\mathrm{D}}=-3.66 \mathrm{~T}_{\mathrm{mB}}+60.5$ & 0.46 & R3b & $\Delta R F$ & P2 \\
\hline $\mathrm{RF}_{\mathrm{B}-\mathrm{S}}=-4.73 \mathrm{~T}_{\mathrm{mB}}+68.0$ & 0.42 & $\mathrm{R} 3 \mathrm{c}$ & $\mathrm{RF}_{\mathrm{B}-\mathrm{D}}=-4.65 \mathrm{~T}_{\mathrm{mB}}+76.5$ & 0.31 & R3d & $\Delta \mathrm{RF}$ & P3 \\
\hline $\mathrm{SF}_{\mathrm{B}}=-3.161 \mathrm{~T}_{\mathrm{mB}}+42.6$ & 0.3 & $\mathrm{R} 4 \mathrm{a}$ & $S F_{S}=-8.71 T m B+117.7$ & 0.51 & R4b) & SF & $\mathrm{P} 1$; Figure $3 \mathrm{~b}$ \\
\hline$S F_{D}=-12.51 T_{m}+190.2$ & 0.45 & $\mathrm{R} 4 \mathrm{c}$ & & & & SF & $\mathrm{P} 1$; Figure 3b \\
\hline $\mathrm{SF}_{\mathrm{S}-\mathrm{B}}=-4.67 \mathrm{~T}_{\mathrm{mB}}+64.92$ & 0.61 & R5a & $S F_{D-B}=-10.62 T_{m B}+163.6$ & 0.47 & R5b & $\Delta \mathrm{SF}$ & P1 \\
\hline $\mathrm{SF}_{\mathrm{S}-\mathrm{B}}=-6.41 \mathrm{~T}_{\mathrm{mB}}+86.5$ & 0.74 & $\mathrm{R} 5 \mathrm{c}$ & $\mathrm{SF}_{\mathrm{D}-\mathrm{B}}=-8.10 \mathrm{~T}_{\mathrm{mB}}+142.6$ & 0.32 & R5d & $\Delta \mathrm{SF}$ & P2; Figure A1a \\
\hline $\mathrm{SF}_{\mathrm{S}-\mathrm{B}}=-1.20 \mathrm{~T}_{\mathrm{mB}}+17.96$ & 0.46 & R5e & $\mathrm{SF}_{\mathrm{D}-\mathrm{B}}=-12.27 \mathrm{~T}_{\mathrm{mB}}+181.72$ & 0.56 & R5f & $\Delta \mathrm{SF}$ & P3; Figure A1b \\
\hline $\mathrm{SS}_{\mathrm{B}}=-2.85 \mathrm{~T}_{\mathrm{mB}}+39.39$ & 0.41 & $\mathrm{R} 6 \mathrm{a}$ & $\mathrm{SS}_{\mathrm{S}}=-13.98 \mathrm{~T}_{\mathrm{mB}}+215.1$ & 0.59 & R6b & ss & P1; Figure 4a \\
\hline $\mathrm{SS}_{\mathrm{D}}=-12.37 \mathrm{~T}_{\mathrm{mB}}+238.7$ & 0.45 & $\mathrm{R} 6 \mathrm{c}$ & & & & SS & P1; Figure 4a \\
\hline $\mathrm{SS}_{\mathrm{S}-\mathrm{B}}=-10.36 \mathrm{~T}_{\mathrm{mB}}+166.4$ & 0.5 & $\mathrm{R} 7 \mathrm{a}$ & $\mathrm{SS}_{\mathrm{D}-\mathrm{B}}=11.25 \mathrm{~T}_{\mathrm{mB}}+222.5$ & 0.41 & R7b & $\Delta S S$ & P1 \\
\hline $\mathrm{SS}_{\mathrm{S}-\mathrm{B}}=-8.55 \mathrm{~T}_{\mathrm{mB}}+182$ & 0.5 & R7c & $\mathrm{SS}_{\mathrm{D}-\mathrm{B}}=-6.2 \mathrm{~T}_{\mathrm{mB}}+202.6$ & 0.3 & R7d & $\Delta S S$ & P2; Figure 4b \\
\hline $\mathrm{SS}_{\mathrm{S}-\mathrm{B}}=-6.13 \mathrm{~T}_{\mathrm{mB}}+94.49$ & 0.37 & R7e & $\mathrm{SS}_{\mathrm{D}-\mathrm{B}}=-13.48 \mathrm{~T}_{\mathrm{mB}}+238.4$ & 0.47 & R7f & $\Delta S S$ & P3; Figure 4c \\
\hline $\mathrm{dSF} /\left.\mathrm{dZ}\right|_{\mathrm{BS}}=0.19 \mathrm{SF}_{\mathrm{B}}+9.6$ & 0.93 & R8a & $\mathrm{dSF} /\left.\mathrm{dZ}\right|_{\mathrm{BD}}=0.38 \mathrm{SF}_{\mathrm{B}}+7.2$ & 0.84 & R8d & SF & $\mathrm{P} 1$ \\
\hline $\mathrm{dRF} /\left.\mathrm{dZ}\right|_{\mathrm{BS}}=-0.15 \mathrm{RF}_{\mathrm{B}}+2.4$ & 0.47 & $\mathrm{R} 8 \mathrm{~b}$ & $\mathrm{dRF} /\left.\mathrm{dZ}\right|_{\mathrm{BD}}=-0.08 \mathrm{R} F_{\mathrm{B}}+0.3$ & $\mathrm{nc}$ & R8e & RF & $\mathrm{P} 1$ \\
\hline $\mathrm{dSS} /\left.\mathrm{dZ}\right|_{\mathrm{BS}}=0.07 S_{\mathrm{B}}+34$ & $\mathrm{nc}$ & $\mathrm{R} 8 \mathrm{c}$ & $\mathrm{dSS} /\left.\mathrm{dZ}\right|_{\mathrm{BD}}=-0.07 S S_{\mathrm{B}}+21.8$ & $\mathrm{nc}$ & $R 8 f$ & ss & $\mathrm{P} 1$ \\
\hline$S S=-17.78 T_{m}+170$ & 0.56 & $\mathrm{R} 9 \mathrm{a}$ & $S F=-14.09 T_{m}+106.7$ & $\mathrm{nc}$ & $R 9 b$ & SS/F & P1; Figure 5a \\
\hline$R F=-0.269 T_{m}+37.02$ & $\mathrm{nc}$ & R9c & & & & $\mathrm{RF}$ & P1; Figure 5a \\
\hline
\end{tabular}

Table A1: Spatial, interspatial and interannual temperature, precipitation and snowpack relation with the mean temperature at Bhang.

Period while it is further more at Dhundi in P3 data set. However, the inter-station variability in rain over the period is negligible above $11^{\circ} \mathrm{C}$ at Bhang. The $\Delta \mathrm{RF}$ shortfall at Dhundi in relation to Bhang increases from 24 to $30 \mathrm{~mm}$ when $\mathrm{T}_{\mathrm{mB}}=10.0^{\circ} \mathrm{C}$, whereas at Solang it increases from 20 to $21 \mathrm{~mm}$; while, there is decreased- $\mathrm{RF}_{\mathrm{S}-\mathrm{B}}$ at Solang and increased $-\mathrm{RF}_{\mathrm{D}-\mathrm{B}}$ at Dhundi during $\mathrm{P} 3$, which means that relatively there is more rain at Solang and less rain at Dhundi in P3 than P2. The $\triangle \mathrm{RF}$ shortfall at Dhundi and Solang to Bhang vanishes for $\mathrm{T}_{\mathrm{mB}}$ equal to 16.5 and $17.7^{\circ} \mathrm{C}$, respectively during $\mathrm{P} 2$; while it is 17 and $14.4^{\circ} \mathrm{C}$ during P3. It reveals that the rainfall has increased at Solang and become comparable to the rainfall at lower station, Bhang.

Trend line (relations R5a-f) of snowfall excess $(\Delta \mathrm{SF})$ at Solang and Dhundi to Bhang with $\mathrm{T}_{\mathrm{mB}}$ for P1, P2 (Figure A1a) and P3 (Figure $\mathrm{A} 1 \mathrm{~b})$ are helpful in projecting the snowfall for higher stations at different range of $\mathrm{T}_{\mathrm{mB}}$. The study shows that regression analysis of precipitation with temperature is not valid on the trendlines criteria. So, the differential and cluster properties criteria have been attempted. The centroids of cluster boxes (Figure Ala and Figure Alb) show the changes in snowfall at higher locations from P2 to P3 with reference to temperature and snowfall at Bhang. Snowfall excess $(\Delta \mathrm{SF})$ at Dhundi increases from 142 to $182 \mathrm{~cm}$ whereas it reduces at Solang from 86 to $18 \mathrm{~cm}$ corresponding to $\mathrm{T}_{\mathrm{mB}}=0.0^{\circ} \mathrm{C}$. During $\mathrm{P} 2, \Delta \mathrm{SF}$ at Solang and Dhundi reaches zero for $\mathrm{T}_{\mathrm{mB}}$ above 13.5 and $17.5^{\circ} \mathrm{C}$, respectively $\left(\mathrm{R}^{2}=0.74\right)$. But during $\mathrm{P} 3, \Delta \mathrm{SF}=0.0$ when $\mathrm{T}_{\mathrm{mB}} \geq 14.9^{\circ} \mathrm{C}$. Similar analysis by considering $\mathrm{T}_{\max }$ and $\mathrm{T}_{\min }$ at Bhang has been performed. For $\mathrm{P} 2, \Delta \mathrm{SFS}-\mathrm{B}=0.0$ when weekly $\mathrm{T}_{\max } \geq 20.52^{\circ} \mathrm{C}$ and $\mathrm{T}_{\min } \geq 6.6^{\circ} \mathrm{C}$; while $\Delta \mathrm{SF}_{\mathrm{D}-\mathrm{B}}=0.0$ when $\mathrm{T}_{\max } \geq 24.78^{\circ} \mathrm{C}$ and $\mathrm{T}_{\min } \geq 9.86^{\circ} \mathrm{C}$ at Bhang. On the other hand for $\mathrm{P} 3, \Delta \mathrm{SF}_{\mathrm{S}-\mathrm{B}}=0.0$ or $\Delta \mathrm{SF}_{\mathrm{D}-\mathrm{B}}=0.0$ when weekly $\mathrm{T}_{\max } \geq 22.75^{\circ} \mathrm{C}$ and $\mathrm{T}_{\min } \geq 7.4^{\circ} \mathrm{C}$ at Bhang. It shows that snowfall during P3 is ceased at Dhundi with drop in temperature of $2.03^{\circ} \mathrm{C}$ $\left(\mathrm{T}_{\max }\right), 2.46^{\circ} \mathrm{C}\left(\mathrm{T}_{\min }\right)$ and $2.6^{\circ} \mathrm{C}\left(\mathrm{T}_{\mathrm{mB}}\right)$ while at Solang with rise in temperature of $2.23^{\circ} \mathrm{C}\left(\mathrm{T}_{\max }\right), 0.8^{\circ} \mathrm{C}\left(\mathrm{T}_{\min }\right)$ and $1.4^{\circ} \mathrm{C}\left(\mathrm{T}_{\mathrm{mB}}\right)$ at Bhang. This reveals the reversal impact of partial duration snow cover (Solang) and full duration snow cover (Dhundi) on snowfall disappearance temperatures, which require a separate study.

\section{A3. Precipitation phase with temperature}

The following relations of UBC [34] and Kienzle [21] have been used for the comparison of change in phase of precipitation on temperature.

$$
\text { Prain }=\left(\mathrm{T}_{\mathrm{m}} / \mathrm{TR}\right)-\mathrm{c}
$$

Prain $=5\left(\left(\mathrm{~T}_{\mathrm{m}}-\mathrm{T}_{\mathrm{crs}}\right) /(1.4 \mathrm{TR})\right) \wedge 3+6.76\left(\left(\mathrm{~T}_{\mathrm{m}}-\mathrm{T}_{\mathrm{crs}}\right) /\right.$

$(1.4 \mathrm{TR}))^{\wedge} 2+3.19\left(\left(\mathrm{~T}_{\mathrm{m}}-\mathrm{T}_{\text {crs }}\right) /(1.4 \mathrm{TR})\right)+0.5$

Prain $=5\left(\left(\mathrm{~T}_{\mathrm{m}}-\mathrm{T}_{\mathrm{crs}}\right) /(1.4 \mathrm{TR})\right)^{\wedge} 3-6.76\left(\left(\mathrm{~T}_{\mathrm{m}}-\mathrm{T}_{\mathrm{crs}}\right) /\right.$ $(1.4 \mathrm{TR}))^{\wedge} 2+3.19\left(\left(\mathrm{~T}_{\mathrm{m}}-\mathrm{T}_{\mathrm{crs}}\right) /(1.4 \mathrm{TR})\right)+0.5$

where Prain=precipitation factor for the rain portion $[0$ to 1$]$; $\mathrm{TR}=$ temperature range $\left(\mathrm{T}_{\mathrm{rf}}-\mathrm{T}_{\mathrm{sf}}\right)\left[{ }^{\circ} \mathrm{C}\right] ; \mathrm{T}_{\mathrm{rf}}=$ temperature for only rain or no fresh snow $\left[{ }^{\circ} \mathrm{C}\right] ; \mathrm{T}_{\mathrm{sf}}=$ temperature for only snow, no rainfall $\left[{ }^{\circ} \mathrm{C}\right]$; 
Citation: Verdhen A, Chahar BR, Sharma OP (2016) Winter Precipitation and Snowpack-melt with Temperature and Elevation at Solang Valley, India. Hydrol Current Res 7: 245. doi:10.4172/2157-7587.1000245

Page 10 of 11

$\mathrm{T}_{\mathrm{crs}}=$ mean critical temperature $\left[{ }^{\circ} \mathrm{C}\right]$; term $\mathrm{c}=0.04$; Kienzle Equation (A.3a) is for $\mathrm{T}_{\mathrm{m}} \leq \mathrm{T}_{\text {crs }}=4.4$ and Equation (A.3b) is for $\mathrm{T}_{\mathrm{m}} \geq \mathrm{T}_{\text {crs }}$.

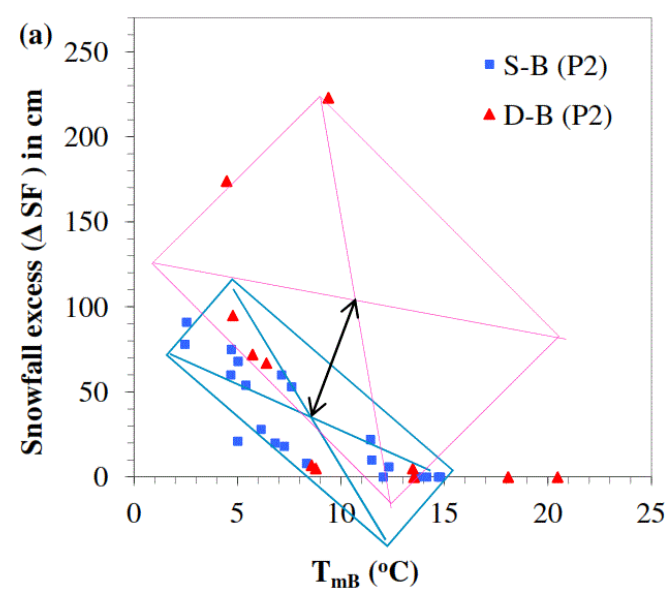

Figure A1a: Weekly differential precipitation with $\mathrm{T}_{\mathrm{mB}}$ for $\mathrm{SF}_{\mathrm{S}-\mathrm{B}}$ and $\mathrm{SF}_{\mathrm{D}-\mathrm{B}}$ including rectangular-cluster's centroids under $\mathrm{P} 2$.

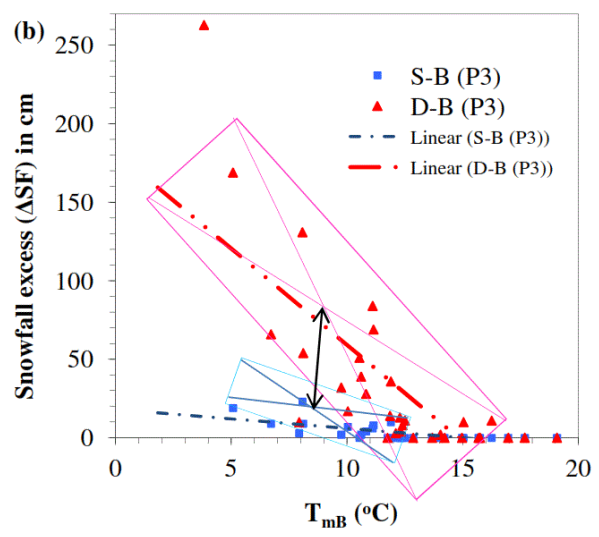

Figure A1b: Weekly differential precipitation with $\mathrm{T}_{\mathrm{mB}}$ for $\mathrm{SF}_{\mathrm{S}-\mathrm{B}}$ and $\mathrm{SF}_{\mathrm{D}-\mathrm{B}}$ including cluster's centroid under $\mathrm{P} 3$.

\section{References}

1. Martinec J, Rango A, Roberts R (1994) Snowmelt runoff model (SRM) user's manual. In: Baumgartner MF (Eds.) University of Bern, Geographica Bernesia: Bern, p: 29.

2. Rao NM, Bandopadhyay, BK, Verdhen, A (1991) Snow hydrology study in Beas basin for developing snowmelt runoff model. J Institution of Engineers CEV72: 92-102.

3. Rango AS, Martinec J (1998) Effects of global warming on runoff in mountain basins representing different climatic zones. Hydrology in Changing Environment. In: Weater H, Kirby C (Eds.), J Wiley Chichester 1: 133-139.

4. Hock R (2003) Temperature index modelling in mountain area. J Hydrol 282: 104-115.

5. Whitaker AC, Sugiyama H (2005) Seasonal snowpack dynamics and runoff in a cool temperate forest: lysimeter experiment in Niigata, Japan. Hydrological Processes 19: 4179-4200.
6. Mote PW (2006) Climate driven variability and trends in mountain snowpack in western North America. J Climate 19: 6209-6220.

7. Pohl S, Marsh S (2006) Modelling the spatial-temporal variability of spring snowmelt in an arctic catchment. Hydrol Process 20: 1773-1792.

8. Verdhen A (1989) Hydrological study in a glaciated mountain stream. Proc of the National Meet on Himalayan Glaciology, Dept. of S and T India, pp: 33-42.

9. Wagnon P, Linda A, Arnaud Y, Kumar R, Sharma P, et al. (2007) Four years of mass balance on Chhota Shigri glacier, Himachal Pradesh, India, a new benchmark glacier in the western Himalaya. Journal of Glaciology 53: 603-611.

10. Holden J, Rose R (2010) Temperature and surface lapse rate change: a study of the UK's longest upland instrumental record. Intr. J Climatology 31: 907-919.

11. Hayakawa N, Lu M (2000) Distribution of temperature and precipitation in the snowmelt runoff analysis. In Proceedings of Joint Conference on Water Resources Engineering and Water Resources Planning and Management, Minnesota, USA, pp: 1-5.

12. Pepin NC (2000) Twentieth century changes in the climate record for the Front Range, Colorado, USA. Arctic, Antarctic and Alpine Research 32: 135-146.

13. Lai LW, Cheng WL (2010) Change due to human activities in Taiwan for the past century. Intr. J. Climatology 30: 432-444.

14. Shekhar MS, Chand H, Kumar S, Srinivasn K, Ganju A (2010) Climatechange studies in the western Himalaya. Annals of Glaciology 51: 105-112.

15. Svoma BM (2011) Short communication: Trends in snow level elevation in mountains of central Arizona. Intr J Climatology 31: 87-94.

16. DeBeer CM, Pomeroy JW (2010) Simulation of the snowmelt runoff contributing area in a small alpine basin. Hydrology and Earth System Sciences 14: 1205-1219.

17. Leavesley GH, Markstorm SL, Restrepo PJ, Viger RJ (2002) A modular approach to addressing model design, scale, and parameter estimation issues in distributed hydrological modelling. Hydrol Process 16: 173-187.

18. Mernild SH, Liston GE, Hasholt B, Knudsen NT (2006) Snow distribution and melt modeling for Mittivakkat glacier, Ammassalik Island, Southeast Greenland. J Hydrometeorology 7: 808-824.

19. Ferguson RI (1984) Magnitude and modelling of snowmelt runoff in the Cairngorm Mountains, Scotland. Hydrological Science Journal 29: 49-62.

20. Fitzharris BB (1978) Problems in estimating snow accumulation with elevation on New Zealand Mountains. J Hydrology 17: 78-90.

21. Kienzle SW (2008) A new temperature based method to separate rain and snow. Hydrol Process 22: 5067-5085.

22. ShiQiao Z, ShiChang K, TanGuang G, GuoShuai Z (2010) Response of Zhadang Glacier runoff in Nam and Co Basin, Tibet, to changes in air temperature and precipitation form. Chinese Science Bulletin 55: 2103-2110.

23. Leathers DJ, Ellis AW, Robinson DA (1995) Characteristics of temperature depressions associated with snow cover across the northeast US. J Applied Meteorology 34: 381-390.

24. Scott PA, Rouse WR (1995) Impacts of increased winter snow cover on upland tundra vegetation: a case example. J Climate Research 5: 25-30.

25. Rebetez M (1996) Seasonal relationship between temperature, precipitation and snow cover in a mountainous region. Theoretical Applied Climatology 54: 99-106.

26. Fallot JM, Barry RG, Hoogstrate D (1997) Variations of mean cold season temperature, precipitation and snow depths during the last 100 years in the former Soviet Union. Hydrological Science Journal 42: 301-327.

27. Gyalistras D (2003) Development and validation of a high- resolution monthly gridded temperature and precipitation data set for Switzerland. Climate Research 25: 55-83.

28. Anderson EA (1973) National Weather Service River Forecast System snow accumulation and ablation model. NOAA Technical Memorandum NWS Hydro 17. 
Citation: Verdhen A, Chahar BR, Sharma OP (2016) Winter Precipitation and Snowpack-melt with Temperature and Elevation at Solang Valley, India. Hydrol Current Res 7: 245. doi:10.4172/2157-7587.1000245

Page 11 of 11

29. Moore RD, Owens IF (1984) Modelling Alpine snow accumulation and ablation using daily climate observations. J Hydrology 23: 73-83.

30. Hannah DM, McGregor GR (1997) Evaluating the impact of climate on snow- and ice-melt dynamics in the Taillon basin, French Pyrenees. J Glaciology 43: 563-568.

31. Datt P, Srivastava PK, Negi PS, Satyawali PK (2008) Surface energy balance of seasonal snow cover for snowmelt estimation in NW Himalaya. J Earth System Science 117: 567-573.

32. Kasurak A, Kelly R, Brenning A (2011) Linear mixed modelling of snow distribution in the central Yukon. Hydrol Process 25: 3332-3346.

33. Verdhen A (2013) Snow and glacier melt simulation for hydrology in a typical Himalayan watershed. PhD Thesis, Indian Institute of Technology Delhi, India.
34. Pipes A, Quick MC (1977) UBC Watershed Model Users Guide Department of Civil Engineering, University of British Columbia: Vancouver, British Columbia Canada.

35. Verdhen A, Chahar BR, Sharma OP (2014) Spring time snowmelt and streamflow predictions in the Himalayan Mountains. J Hydrol Engrg 19: 1452-1461.

36. Verdhen A, Chahar BR, Ganju A, Sharma OP (2015) Modeling snow line altitudes in the Himalayan Watershed. J Hydrol Engineering 21: 1-10.

37. Verdhen A, Chahar BR, Sharma OP (2014) Snowmelt modelling approaches in watershed models: computation and comparison of efficiencies under varying climatic conditions. Water Resour Manage 28: 3439-3453. 